\title{
Utilization Strategy and Management of Green Waste to Improve Wasteland Fertility in Australia
}

\author{
Divyesh Shekhada* \\ Master's degree candidate, School of natural and built environments, University of South Australia, Mawson Lakes, \\ Australia \\ divyeshshekhada007@gmail.com
}

\begin{abstract}
This paper covers production of food waste in Australia, including to find the best solution to address the food waste issue by collective understanding of what we mean by food waste and where it happens. Recognizing what we are starting at now do well can empower us to take in and use from prevailing exercises and moreover development. Moreover, the point of administration and recycling of food waste in header of biomass preparation can build soil fertility of wasteland in Australia. With the aim of considering natural composts are infinite, biodegradable, reasonable, and ecologically attractive. This thought can be proposed as reusing of waste as a natural fertilizer to enhance soil readiness of wasteland in Australia.
\end{abstract}

Keywords-food waste, management, organic, environment, economic, natural resource management.

\section{INTRODUCTION}

The definition of food waste differs worldwide it depends on from where food waste occurs into the food supply chain to consumption. For example, whether it, contains or discounts inedible waste of food.

Food waste is simply defined as the quantitative or qualitative reduction of food. Definition of food waste also covers solid or liquid kinds of food that is occurred from human consumption during the complete consumption and supply chain. It is part of food loss, refers to avoidance of alternative use and disposal of food. Moreover, Food is key component in whole food supply chain, from primary production to the level of household consumer. Because, it is a significant source of nutrition for human consumption. However, majority of food waste is generating by the consumers (FAO, 2014).

\section{BACKGROUND}

According to FAO (Food and Agriculture Organization of the United Nations) report (2011) the estimated global annual food waste was approximately one-third from total production of food that means every year, we lost $25 \%$ consumable food world-wide. This report also indicated that the per capita food waste is in Europe and NorthAmerica as compare to Africa and South/Southeast Asia. It is 95 to 115 and 6 to $11 \mathrm{kgs} /$ year respectively. Moreover, if we look at Australia the generation of food waste is higher than others because, in the year of 2014-2015 Australia produced around 64 million tons food waste that means individual person food waste is $2700 \mathrm{kgs} /$ year (Australian National Waste Report, 2016).

In Australia, government supporting to reduce food waste in AgriFutures Australia industry, CSIRO (Commonwealth Scientific and Industrial Research Organization) and Cooperative Research Centers by investing more than $\$ 10$ million annually. To encourage the developmental research on higher-value products from recovered or converted food waste such as, kitchen, organic and green waste management (e.g. vegetables, non-veg., and garden waste, leaf cutting, trimming etc.) by developing alternative markets and advance digital technologies.

What's more, Australia has a strong dependence on landfill as a sort of waste organization. Most of the waste that isn't reused or re-used in Australia is disposed of in the nation's landfills. While, as indicated by, the administration report (2016) states that Australia creates approximately 64 million tons of waste a year, apart from around $40 \%$ isn't reused.

\section{CHALLENGES FOR FOOD WASTE}

Australia has complex challenges for management of the food waste. Because, there are large numbers of outlet units are engaged in supply chain throughout producing, moving, selling, redistributing and disposing food. Firstly, there are several challenges in procurement for appropriate quantities and feedstock to have access market for the end products. Secondly, the Australian local, territory and state governments has an additional layer of complexity as a role of legislative requirements, environmental and human health policy. Thirdly, households are also important part of food waste in Australia. Finally, global Greenhouse gas 
(GHG) emissions have twisted eight per cent due to more use of water in agriculture (National Food Waste Strategy Report, 2017). This scope of waste needs to encourage a large amount of initiatives to address food waste issue across the world.

\section{SOCIAL ASPECTS}

\section{WASTE GENERATION ANALYSIS}

The drivers of sustenance squander are changed and complex and happen at each point along the supply and utilization chain. Models of how sustenance waste can happen are plot beneath.

\section{Primary Production}

At initial stage, food waste occurs when item misfortune because of irritations and illnesses or climate, stock or harmed or disposed of amid creation, pressing or dealing with fall in market costs making it unrewarding to gather. Moreover, failure to meet contracted create, determinations, for example, quality or size. Changes in purchaser tastes and inclinations.

\section{Processing and manufacturing}

This kind of waste occurs when food product harmed amid taking care of, due to deterioration because of tainting or deficient. Over the top trimming of vegetables for handling and changes underway because of buyer request. Spillage on transport lines and exchange focuses, harm to bundling bringing about sustenance unfit as well.

\section{Retail Stores}

Retailers are also included in waste generation, there are several reasons because of poor stock administration, including over requesting, inappropriate stock pivot, stockpiling and taking care of practices. Furthermore, deliver never again meets quality models and very late request changes that can leave providers with overabundance item. Constrained access to offices to reuse or repurpose nourishment squander.

\section{Household}

Family squander happens amid disarray over 'use-by' and 'best-previously' date marking and over-obtaining of sustenance that is then discarded. Constrained information of how to securely repurpose or store sustenance remains and restricted access to nourishment squander accumulation frameworks.

\section{HOW MUCH FOOD WASTE PRODUCED BY AUSTRALIA?}

Australia is one of the most elevated makers of waste per head of populace on the planet. In 1999, Australia positioned second, behind the USA, as far as local waste age. Generally, Australians discarded $\$ 2.9$ billion of crisp sustenance, $\$ 630$ million of uneaten takeaway nourishment, \$876 million of scraps, \$596 million of incomplete beverages and $\$ 241$ million of solidified sustenance, an aggregate of $\$ 5.3$ billion on all types of sustenance in 2004.

Looks at the aggregate waste created, arranged and recouped per capita in chosen OECD countries. Vitality recuperation was incorporated where information was accessible. (Figure 1) The way that they contrast implies the correlations ought to be utilized with the alert.

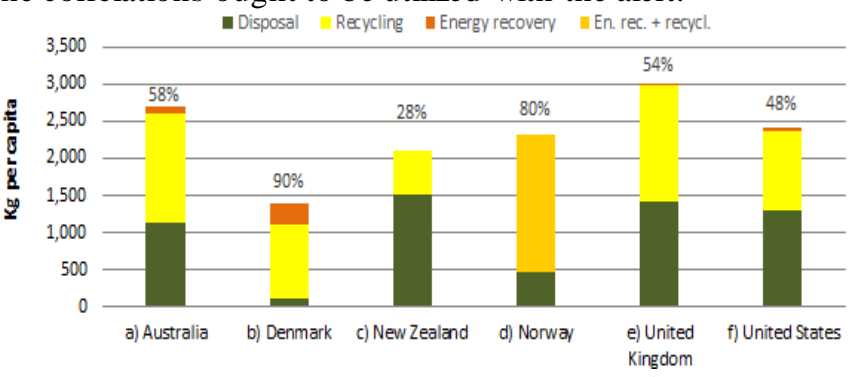

Fig.1: Comparison of waste generation and fate per capita, Australia and selected OECD countries (Pickin and Randell, 2017).

\section{ECONOMIC ASPECT}

\section{WASTE HIERARCHY}

This technique embraces a roundabout economy approach that considers the sustenance squander pecking order and looks to catch nourishment squander as an asset, so it isn't sent to landfill. The waste progression organizes squander administration rehearses in favoring sustenance squander shirking over asset reuse, reusing, reprocessing, and vitality recuperation, trailed by waste transfer. Moreover, the pecking order perceives the natural estimation of nourishment squander in giving direction on the most asset proficient and earth sound ways to deal with managing waste.

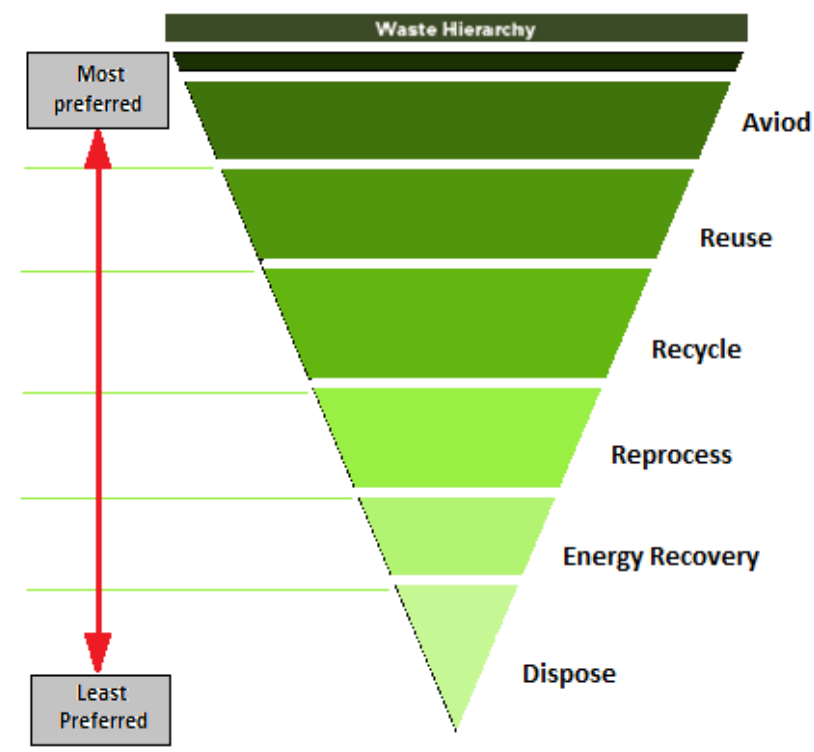

Fig.2: Waste hierarchy (Modified from NFWS, 2017)

The utilization of round economy approaches and the waste chain of command to address sustenance squander 
requests a more vital and synergistic approach. This will move us to discover arrangements over the whole nourishment framework as opposed to proceeding to work inside single, straight supply and utilization chains. Moreover, the structure and healthy benefit of sustenance squander is essential to figure out where esteem including can be connected. Access to data on the volume, type and wholesome piece of nourishment squander helps with supporting venture choices on item improvement. For instance, sustenance squander that can be utilized for treating the soil (NFWS, 2017).

\section{UTILIZATION OF GREEN WASTE OR ORGANIC WASTE}

Treating the soil or aging sustenance waste can give cost sparing to neighborhood experts in waste administration and decrease cost spent in decline gathering and waste transfer. By delivering manures from waste materials, the expense of purchasing business composts that give supplements to plant and soil can be lessened. The manures created can be utilized as natural composts for soil molding and sustenance. The manure produces materials that can be utilized as moderate discharge compost in a manor. The fulfilment can be picked up from the enhanced development and improvement of plants in fertilizer revised soil.

Sustenance squander age and destiny by source segment. The lion's share - around 3.1 Mt or $133 \mathrm{~kg}$ for each capita - was from household sources. Around 6\% (0.2 Mt) of gathered MSW nourishment squander was reused, principally through treating the soil (Figure 2).

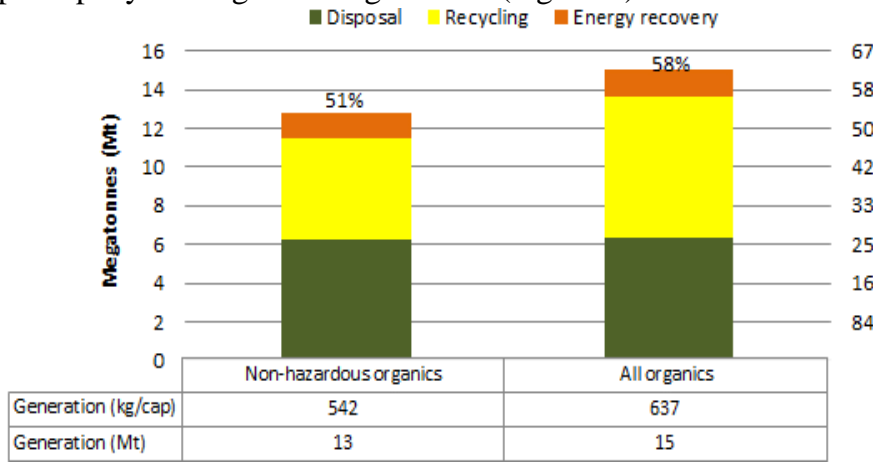

Fig.3: Non-hazardous and hazardous organic waste generation and fate, Australia 2014-15 (Pickin and Randell, 2017).

\section{ENVIRONMENTAL ASPECT}

\section{PREPARATION OF ORGANIC FERTILIZER FROM ORGANIC WASTE}

The manure pile is developed of layers of materials, as in a major sandwich. The essential grouping is

Layer 1: A layer of dry plant materials or mix of dry plant materials with compost making helps like incredible soil, stooland in addition a couple of ashes. The layer should be
20- $25 \mathrm{~cm}$ thick, i.e. as significant as a hand. The compost influencing jars be mixed with the water to make slurry. Water or slurry should be scattered by hand or sprinkled with a watering can consistently over this layer making it saturated yet not sprinkling wet.

Layer 2: A layer of sticky (green) plant materials, either fresh or shriveled, e.g. weeds or grass, plants from clearing a pathway, stems and leaves left completed from gathering vegetables, hurt results of the dirt. Verdant branches from woody plants can moreover be used as long as the materials are tidied up. The layer should be $20-25 \mathrm{~cm}$ thick. Water should NOT be sprinkled or scattered over this layer.

Layer 3: A layer of animal fertilizer assembled from new or dried cow-like excrement, horse, jackass or ass compost, sheep, goat or chicken droppings. The animal fecal matter can be mixed with soil, old excrement and a couple of slags to make a layer $5-10 \mathrm{~cm}$ thick. In case there is only a little measure of animal dung, it is best to mix it with water to make slurry, and after that spread it over as a thin layer $1-2 \mathrm{~cm}$ thick. At last, in the wake of treating the soil time of 5 two months it will be prepared with loaded with dietary parts to use as a natural fertilizer to enhance soil richness.

The transformation of food waste into natural composts by aging, strong state aging or fertilizing the soil is generally led to diminishing the measure of sustenance squander created day by day. Nourishment squanders that isn't dealing with legitimately can cause sullying of groundwater, discharge of harmful gas, a spread of scent and fascination of vermin. The best possible disintegration of sustenance waste can cause a decrease of pathogen and smell. Nourishment waste, for example, natural products, vegetables, grain, bread and eggshells can be made and changed over into natural manures. Nourishment waste, for example, red meat and bones likewise can be made however they take a more extended period to form.

Furthermore, nourishment squander is broadly reused into natural manure since sustenance squander has exceptional includes as crude manure specialist. Sustenance squander contains high vitality and is appropriate for vitality creation and waste adjustment. Moreover, the proportion of carbon to supplements of natural squanders is critical amid maturing and treating the soil procedure. These procedures rely upon a microorganism that utilizations carbon source to give vitality and nitrogen to as semble cell proteins. Vegetable and organic product squanders have $\mathrm{C}$ : $\mathrm{N}$ proportion of $\leq 27: 1$ is reasonably appropriate in maturation and fertilizing the soil (Ahmad et al. Cited in Min, 2015). 


\section{INCREASE SOIL FERTILITY OF WASTELAND BY USING ORGANIC FERTILIZER}

The primary components in treating the soil sustenance squander are physical and compound attributes of a substrate which incorporate the structure and molecule estimate. Sustenance squander has high dampness substance and low physical structure when contrasted with sewage muck and excrement. Nourishment squander is blended with building specialists, for example, yard waste and sawdust that contain high $\mathrm{C}$ : $\mathrm{N}$ proportion to assimilate more dampness and add structure to the blend along these lines upgrading treating the soil of sustenance squander.

\section{NATURAL RESOURCE STRATEGY}

Australia is the 6th biggest nation on the planet by region (393,797,177 ha). According to, Australian Bureau of Statistics report (2011) emphasis that, roughly 53\% of Australia's aggregate land zone was utilized for farming. Apart from southern hemisphere has big amount of wasteland in Australia including mountains, rocky area, bare lands or which can be not utilized in Agriculture purpose due to nutrition deficiency. To improve or balance nutritional deficiency of soil required tons of fertilizer. The fertilizer containing chemicals which have unaffordable prized or cost. To revel from cost re3duction problem the manure preparation from organic and kitchen waste will be a novel step towards improvement of non-fertile lands.

How much land can be productive by using organic compost?

In March 2011, a pilot venture began with a fertilizing the soil office in the surroundings of Kathmandu, Nepal. The plant gathers squander from vegetable markets creating manure through vigorous corruption and in the meantime decreasing methane emanations. Amid the pilot, altogether 140 tons of new natural waste from neighborhood markets were gathered and $\mathbf{1 5}$ tons of organic fertilizer was created (Gnirrep, 2018). So, that mean from total 64 million tons organic waste can be useful to prepare 6.9 million tons organic fertilizer.

\section{CALCULATION AND ANALYSIS BY USING BASE STUDY}

$=140$ tons natural waste required to make 15 tons organic manure (As per base study)

$=64$ million tons $(64,000,000$ tons $)$ total organic waste generate Australia every year

$=(140$ tons organic waste $=15$ tons organic manure $)$

$=(140 / 15)=9.3$ tones organic waste

(. that means, to produce 1 ton organic manure, 9.3 tons waste is required)

$=140$
$=64,000,000$

$=(64,000,000 \times 15 / 140)=68,57,142.8$ (6.9 million tons $)$

(. a available waste can be utilized, to produce 6.9 million tons organic manure)

According to Madison et al. (1995) states that, at a most extreme application rate of natural fertilizer is 25 tons/ 1 acer for every section of land every year without consolidation. It means, this fertilizer can be used to recover 274,285.6 acres of unfertile lands in Australia every year at very low cost.

$=(68,57,142.8 \times 1 / 25)=274,285.6$ acres $(110$ Million Meter Square)

\section{Important for waste recycling and utilization}

Unproper discarding of waste creates terrific contamination the environment by proper utilization of waste. This waste can be turns into pathogen fee manure, so it will be an eco-friendly procedure.

The manure prepared by using the waste will help to improve soil fertility. Moreover, this type of agricultural land can be utilized for ZBNF (Zero Budget Natural Farming) and organic farming.

Additionally, treated the dirt material is less awkward than the primary material and less complex and all the more beguiling to manage. In the midst of the treating the dirt technique, carbon dioxide and water are lost to the atmosphere and the proportion of the pile lessens by 30$60 \%$. Likewise, many weed seeds and disorder causing animals may be killed by the high temperatures in the stack. Annoying scents are wiped out. Flies, a regular is sue around waste products and other characteristic misuses, are generously less of an issue with composts. Treating the dirt declines or takes out the reduction in nitrogen availability that routinely happens when normal materials, for instance, sawdust or straw, are added particularly to the soil. Preparing the dirt is furthermore uncommonly supportive for reusing kitchen misuses, additional item developments, weeds, and manures. Various sorts of neighborhood normal waste, for instance, apple pumice, lake weeds, leaves, and grass clippings, can be dealt with the dirt.

\section{BENEFITS FROM ORGANIC COMPOST}

Manures are natural or inorganic, normal or engineered substances that additional to soil to improve plant development and creation. Plants rely upon the supplements in soil to complete metabolic responses since soil contains essential synthetic compounds for plant development (Turing et al., 2006). Be that as it may, the supply of essential synthetic concoctions in soil to plants is restricted. At the point when plants are being reaped, the supplement content decreases and causes the decrease of 
amount and nature of plants. Composts are connected to supplant the concoction materials in soil that are used by plants amid development and improvement (Miller Cited in Min, 2015).

Moreover, composts are utilized to upgrade the dirt's developing potential since manures can give a superior developing condition to plants when contrasted with common soil. (Turing et al. Cited in Min, 2015).

Composts give expansive measure of macronutrients, for example, nitrogen, phosphorous and potassium while regular soil may not contain adequate measure of this macronutrients. Manures likewise give follow components, for example, magnesium, calcium and copper that are essential in plant development. Notwithstanding in view of the natural issue present in natural compost, soil structure is enhanced and accordingly the dirt's capacity to clutch water and supplements increments.

Natural compost is wealthy in natural issue, which enables microorganisms to flourish. Natural manure contains carbon as a major aspect of its synthetic cosmetics; and it is the carbon, alongside nitrogen, phosphorus and potassium that feeds microorganisms and empowers them to make supplements accessible for plants in a normally happening organic process. Manufactured manures overflow into our conduits hurting marine life and water quality. Natural composts don't keep running off as effortlessly (if by any means) and are related with soil structure. As indicated by the Organic Trade Association, natural manure likewise expands species biodiversity by $30 \%$ contrasted and manufactured compost.

\section{CONCLUSION}

From the above study it can be concluded that, 64 million tons of waste can be utilized by preparing organic manure annually, to improve soil fertility of 274,285.6 acres wasteland in Australia. Moreover, natural squanders can offer ascent to leachate, methane discharges, scent, vermin and precarious landforms. Alternately, they are a potential wellspring of soil conditioners or vitality. Redirection of organics, either through a division at a source or handling of lingering waste streams, is a noteworthy focal point of city squander administration and a developing number of committees crosswise over Australia give a different canister to natural squanders, including both garden and nourishment wastes. Here, it is recommended that, strategies are strong of sustenance squander shirking, decrease and repurposing with building up an intentional responsibility of government to diminish nourishment squander and empowering enactment to better help sustenance squander decrease and repurposing.

\section{REFERENCES}

[1] Commonwealth of Australia, 2017, 'National Food Waste Strategy: Halving Australia's food waste by 2030', Commonwealth of Australia.

[2] Gnirrep, M, 2018, 'From Waste to Organic Fertilizer', Waste Management and Compost, Kathmandu, Nepal, Viewed on, https://www.myclimate.org/carbon-offsetprojects/projekt/nepalwaste-management-7166/,25 October 2018.

[3] Madison, F, Kelling, K, Massie, L \& Good, L W, 1995, 'Guidelines for applying manure to cropland and pasture in Wisconsin', University of Wisconsin, Extension.

[4] Min, T L, 2015, 'Production of Fertilizer using Food Wastes of Vegetables and Fruits', Bachelor of Science with Honours Plant Resource Science and Management, University Malaysia Sarawak, Malaysia.

[5] Pickin, J and Randell, P, 2017, 'Australian national waste report 2016', DOTEA, Blue Environment Pty, Docklands, VIC, Energy. 